\title{
Origin of Names on the Great Lakes
}

\author{
IVAN H. WALTON
}

$\mathrm{N}$ His SEcond voyage to the New World, Jacques Cartier on August 10, 1535, dropped anchor in a small bay on the north side of a wide estuary that appeared to be the mouth of a large river. It was the feast day of Saint Lawrence, and he named the bay in the saint's honor. Later the name became applied to the whole gulf and also to the wide river which extends $75^{\circ}$ miles inland to the North American Great Lakes. And so was named the New World's most outstanding river system.

Today these lakes and their connecting rivers and the upper St. Lawrence, approximately equal in area to that of the British Isles, form approximately 2000 miles of the peaceful boundary between the United States and the Dominion of Canada. Upon the shores of these inland seas are located six of the twelve largest cities of the United States and an equal proportion of the population and industrial centers of Canada, and over them annually passes a greater commercial tonnage than that of the American Atlantic and $\mathrm{Pa}$ cific ports combined. They have for over three quarters of a century been considered as "high seas" by the governments concerned; and, when the projected improvements in the St. Lawrence above Montreal are completed, they will become open to all but the largest ocean ships, and their importance in the economy of the two bordering nations will be materially increased.

The origins of the present names on these lakes and their connecting rivers and canals is not without interest. Strangely enough the easternmost, or "Lower Lakes," were not the first to be named and represented on contemporary maps. Lake Huron was first, and it took its name from the Indians who at the time inhabited its eastern and southern shores. These people, according to the Jesuit missionary Jerome Lalemant, received their name in a quite un- 
usual manner. In his Relation of $1639^{1}$ he states that about 40 years earlier when some natives from this region appeared at the French trading post, "a sailor or soldier seeing for the first time these species of barbarians, some of whom wore their hair in ridges,-a ridge of hair one or two fingers wide appearing upon the middle of their heads and on either side the same amount being shaved off, then another ridge of hair ... and this fashion of wearing the hair making their heads look like those of boars (hures) led him to call these barbarians 'Hurons,' and this is the name that has clung to them ever since." These Indians referred to themselves as "Wendats," and they have given their name to a Michigan city on the Detroit river.

When Champlain in ${ }_{1615}$ first came upon the wide expanse of the Bay and Lake from which these Indians came, he named it $l a$ Mer Douce, or the Fresh Water Sea. It was also designated as Lac d'Orleans, but the religious workers who early established a mission in their midst near the site of the present city of Midland, Ontario, consistently referred to it as "the Lake of the Hurons," and so designated it in their reports, and so it has remained. The name Huron has since been applied to several counties, rivers, and cities in the larger area.

Georgian Bay, which comprises about one third of the Lake's total area, was named in honor of King George III of England by Henry Wolsey Bayfield when he first surveyed the Lake. ${ }^{2}$ The derivation of the name of the strait which connects Lakes Huron and Michigan is somewhat complicated. An early form of the present name, Mackinac, was first applied only to the island in the strait which had long been a favorite gathering place of the Chippewa nation, and later became a fur trade, missionary, and military headquarters, and a popular resort center. During the French regime the name came to be applied to the surrounding area, including the Straits and adjacent areas of both Michigan Peninsulas.

The first recorded name for the island is that found in the Relations of 1669-167o where Fr. Claude Allouez refers to "a large island named Michilimakinak celebrated among the savages. ${ }^{3}$ The spelling Missilemakina was soon substituted, and in the century following scores of other variant spellings appeared as the writers attempted to reproduce the native Chippewa sounds in French and then in 
English. It is quite probable that a faithful rendition of the Indian name in English is, as Schoolcraft indicates, Mish-i-nim-auk-in-ong. ${ }^{4}$ Usage has shortened the name to its present form, and the island, strait, and county to the north of the strait have retained the French spelling, Mackinac, and the city on the northern tip of the Lower Peninsula uses the English form, Mackinaw, but the pronunciation of both is the same,-it rhymes with "saw."

The name has been given a number of interpretations. The prefix michi (mishi, missi, etc.) conveys the idea of extra largeness in size, and the last syllable ong (ing, in an, etc.) is locative, meaning 'place of.' The various spellings have led to such interpretations as 'home of the giant fairies,' 'place of the giant turtle,' and 'place of the great uplifted bow,' referring to the large natural bridge on the east side of the island. The Ottawa writer Andrew J. Blackbird, states that like many other Indian place names, the word is commemorative. He adds that a tradition among his people has it that the island was anciently inhabited by a friendly Algonquin tribe known as Michilimackinawgos, but they were practically exterminated during one of the early Iroquois invasions, and the island has since been known as the 'place of,' or 'home of' these people. ${ }^{5} \mathrm{Fr}$. William Gagnier, scholar and long time missionary among the Indians of northern Michigan, agrees with this interpretation. ${ }^{6}$

The large body of water to the westward of the Straits, Lake Michigan, also derived its present name from a native original. In the Relations of 1666 , in one of the earliest references to the lake, Fr. Allouez refers to it as Match-i-hi-gan-ing. A few years later Hennepin uses the spelling Misch-i-gon-ong; Marquette, Michigami, and Jolliet, Misschiganin. The Relations provide many other spellings. " Cadillac's Memoir written about 1697, calls it "Lac Michigan ou Ilinois," and later just "Lac Michigan."”

Fr. Gagnier, taking a lead from Schoolcraft, conjectures that the original name was something like Mitchi-Sagaigan, meaning 'very large lake." Blackbird states that the word Michigan, "is an Indian name which we [Ottawas] pronounce Mi-chi-gum, and simply means monstrous lake."10 It can be concluded that the present name is a result of a process of simplification of an Indian original which referred to a vast body of water.

The name of the state of Michigan to the westward and north- 
ward of the lake is, of course, derived from that of the lake itself. The name was applied officially to the land area in 1805 when the United States Congress established the Territory of Michigan.

The northernmost of the Great Lakes, the largest, deepest, and perhaps the grandest, Lake Superior, derived its present name directly from the French missionaries. The Chippewa (Ojibwa) nation, who from ancient times have lived about its shores, referred to it as Kitchi-or Gitchi-Gami, meaning 'great lake or sea'-great not only in size, but in every other way. Fr. Allouez writes in the Relation just referred to that, "The Savages revere this Lake as a Divinity, and offer it sacrifices." He writes of ascending the St. Mary's river to "Lac Superieur, which will henceforth bear Monsieur de Tracy's name in recognition of indebtedness to him on the part of the people of those regions." ${ }^{11}$ Gen. de Tracy had just led an expedition against the Iroquois and put an end to their forays for over a decade.

The name de Tracy, however, never became very deeply rooted, and two years later Fr. Lalemant wrote that "one of our Fathers passed the remainder of the summer and the following winter near the Lake which we call Superieur, from its position above that of the Hurons."12 Our present name is but a translation, or perhaps, a mistranslation, but a happy one as it has much the same connotation as the original Chippewa name.

Lake Superior at the head of the St. Lawrence system empties into Lake Huron through the St. Mary's river which derived its name from one given by two missionaries, Joques and Raymbault, who in 1641 ascended the river by canoe to the rapids where the famous "Soo" locks are now located. The river here makes a spectacular descent of 18 feet through rapids known to the local Indians as Pa-wa-teeg, or Pa-wa-ting, meaning 'strong rapids or cascade.' At this place the missionaries preached to the assembled natives and named the rapids the Saut de Sainte Marie, the 'leap' or 'Falls of St. Mary,' in honor of the Virgin Mary and of their home Mission located near the site of the present city of Midland, Ontario. ${ }^{13}$ The old French spelling Saut has been modernized to Sault, and is popularly known as "the Soo." The two cities that later grew up on either side of the river at this point have dropped the de but retained the French spellings of the other words, and are known today as Sault 
Ste. Marie, Ontario and Michigan. The names of the river and of the famous locks here are both taken from that of the rapids, but in Anglicized form,- - the St. Mary's and the St. Mary's Falls Canals, respectively.

The three Upper Lakes collectively discharge their waters through the St. Clair river, Lake St. Clair, and the Detroit river into Lake Erie. This three-part waterway seems to have been known to the early French as le Détroit, the strait, or it is possible that the term was applied only to the comparatively short waterway between Lake St. Clair and Lake Erie. In 1679, however, the Sieur de La Salle sailed his le Griffin from its building place above the Falls of the Niagara to Green Bay in northwestern Lake Michigan. According to Fr. Louis Hennepin, chaplain on the expedition, they entered the small lake now known as Lake St. Clair on August 12, the festal day of Sainte Claire, and he named it in her honor. ${ }^{14}$ Since the surrender of French Canada to the British, the name has been quite generally Anglicized, yet the French spelling is not unusual.

The name was also, apparently, applied to the river that connects this lake with the larger Lake Huron to the northward, and to the "Flats" at its mouth. There is no evidence available that either the lake or river was named for General Arthur St. Clair, first governor of the Northwest Territory. It is possible, however, that Michigan Territorial governor Louis Cass may have had the General in mind when in 1820 he established and named St. Clair County. It is more probable that he took the name from the river that flows the length of its eastern boundary.

The name "Detroit river" is somewhat of a redundancy, as the French word détroit means a 'strait' or 'waterway.' The word, however, lost that connotation long ago, and at present it simply designates a broad busy river and a highly industrialized city on its northwestern bank. When the French colonial governor Cadillac established a fort and trading post on the site of the present city in 1701, he named it in honor of the minister of colonies under Louis XIV. The fort was frequently referred to as Fort Ponchartrain $d u$ Detroit, and eventually it became simply Detroit, and the strait became the Detroit river.

Our present name for Lake Erie, the last of the five to be discovered, is derived from that of the Indian nation which, at the time 
the first French explorers and missionaries penetrated the region of the Lower Lakes, were living along its southern shore. A map, dated 1656, of "Canada or New France," by N. Sanson d'Abberville, royal geographer of the French king, is the first to show the lake with its present name. He labeled it L. Erie, ou du Chat, that is, 'Lake Erie or of the nation of the Cat. ${ }^{{ }^{15}}$ Charlevoix later stated that the name came from the large number of wild cats found in the region..$^{16} \mathrm{~A}$ more widespread theory is that the name was given by the Iroquois to those Indians in some derision because of their prominent eyes, which characteristic reminded the Iroquois of that animal. The Cat nation was exterminated by the Iroquois shortly after mid century.

The Lake evidently acquired other names as well. Coronelli's map of New France, published in Paris in 1688, identifies it as, Lac Erie ou Teiocharontiong et Lac de Conty et du Chat. ${ }^{17}$ The early name Erie, has, however outlasted all others.

The $3^{6} 3$-mile-long canal between Lake Erie and the Hudson river, first opened in 1825 , takes its name, "The Erie Canal," from the lake at its western terminus. It has been deepened and otherwise improved on several occasions, and its official name has been changed to "The New York State Barge Canal," but it is known quite universally under its old name.

The Welland Ship Canal, roughly parallel to the Niagara river and 20 miles to the westward, raises and lowers vessels the 327 feet difference between the levels of Lakes Erie and Ontario. Like the Erie and the St. Mary's canals, it also has been improved on several occasions and its original 40 locks reduced to eight and greatly enlarged, and its old name modified to that given above, but in popular parlance it is still known as "The Welland Canal," a name adopted from the river whose course the original canal followed for some distance. The river, in turn, was named by Lt. Gov. Simcoe in 1792 for the Welland river in Lincolnshire, England. ${ }^{18}$

The river outlet of Lake Erie, which is broken by the Niagara Falls, was known to the settlements of the St. Lawrence and to the home government in France some time before any European is known to have beheld its wonders. Indian traders had, no doubt, carried descriptions eastward. The map of Marc Lescarbot, published in France as early as 1609 , shows a saut, 'falls,' in approximately their present location. ${ }^{10}$ Champlain's maps of 1612 and 1632 also show a waterfall at the western end of Lac S. Louis (Lake On- 
tario), but he obviously had not seen it, nor did he record any name.

The first recorded name appears in the Relation of 1641 , from Lalemant to his superior. Attempting to reproduce the local Indian name with its apparent deep gutturals, he spelled it Onguiaahra. ${ }^{20}$ Sanson's map referred to above, shortened it to Ongiara Sault. Many other spellings appear in the writings of the period, and four decades pass before Hennepin in his Louisiane wrote it "Niagara," and helped to establish its present form. ${ }^{21}$

The word probably originated with the Huron or Neuter Indians, those most closely associated with the river and with whom the first missionaries worked. It has also been attributed to the Mohawks of the Iroquois group; and it has been interpreted as meaning 'a neck' or 'strait,' and also as 'thunderer of waters. ${ }^{22}$

Lake Ontario, being the nearest to the early St. Lawrence settlements, should have been the first to be discovered and named, but it lay in the country of the powerful Iroquois Confederation, the enemies of the Algonquins and, from Champlain's day, of the French as well. Their country was as a result, not as open to the explorers as were the more northerly regions.

As indicated on his map of 1632 already referred to, Champlain ignored the local Indian name of this lake as he had done a few years earlier when he labeled Lake Huron as la Mer Douce, and he named it Lac S. Louis for the far away French king. Sanson's maps of $165^{\circ}$ and $165^{6}$ repeat this name. The missionaries, always more sensitive to the ways of the Indians than were the government officials, preserved many of the local names. Fr. Brébeuf in his Relation of 1635 refers to this body of water as the Lake of the Hiroquois. ${ }^{23}$ Fr. Lalemant in ${ }^{16} 61$ refers to it by its present name, as DeLaet hàd done two years earlier, and he adds, perhaps diplomatically, ou St. Louys. A few years later Fr. Raugeneau in his Relation of $1647-1648$ refers to "a lake named Ontario which we call Saint Louys." In 1654 Fr. Le Moyne wrote simply of "a great lake called Ontario."

There seems to have been some uncertainty during the next few decades regarding the name of this lake. On his map referred to above, Coronelli, as he also did for Lake Erie, gathered up all the current names, and he labeled it "Lac Frontenac ou Ontario et Skaniadorio ou St. Louis." During the following years, however, the Indian name superseded all others, and today the lake is known 
as Ontario, a beautiful name, said by a recent writer to mean 'beautiful lake."24

The British North American Act of 1867 gave the name to 407,000 square miles of territory that had formerly been known as Upper Canada. The name also designates several counties, townships, cities, and rivers on both sides of the international boundary.

Leaving Lake Ontario through its outlet among the picturesque Thousand Islands at its lower end, we are once more upon the broad and swift waters of the St. Lawrence river, and we realize far more than Cartier ever dreamed the extent of the honor he paid a little known saint when he unwittingly named North America's greatest river system for him.

\section{NOTES}

${ }^{1}$ The Jesuit Relations and Allied Documents, 1610-1791, ed. by Ruben Gold Thwaites, Cleveland, The Burrows Brothers Company, 1899, 16 (1639) 229-231. Subsequent references to these documents will be designated as Relations.

${ }^{2}$ Fred Landon, Lake Huron, New York, Bobbs-Merrill Company, 1944, p. 147.

${ }^{3}$ Relations, 54, p. 201.

${ }^{4}$ Henry Rowe Schoolcraft, Thirty Years with the Indian Tribes, Philadelphia, Lippincott, Grambo and Company, 1851, p. 443.

${ }^{5}$ Andrew J. Blackbird, History of the Ottawa and Chippewa Indians, Ypsilanti, Mich., 1887 , p. 89 .

${ }^{6}$ William Gagnier, "Indian Place Names in the Upper Peninsula," Michigan History Magazine, 2 (July 1918), 527-528.

${ }^{7}$ W. L. Jenks, "History and Meaning of County Names," Michigan Pioneer and Historical Collections, 38 (1912) 440-442.

${ }^{8}$ Wisconsin Historical Collections, 16, p. 351 .

${ }^{9}$ Gagnier, op. cit., p. 547.

${ }^{10}$ Blackbird, op. cit., p. 93 .

${ }^{11}$ Relations, 50, p. 265.

${ }^{12}$ Relations, 45 , p. 219.

${ }^{13}$ Schoolcraft, op. cit., p. 114 .

${ }^{14}$ F. Clever Bald, Michigan in Four Centuries, New York, Harper Brothers, 1954, p. 40 .

${ }^{15}$ Frank H. Severance, An Old Frontier of France, New York, Dodd, Mead and Company, 1917, I, p. 6.

${ }^{10}$ Wm. Martin Beauchamp, Aboriginal Place Names in New York, Albany, State

Education Dept., 1907.

${ }^{17}$ Severance, op. cit., p. 7.

${ }^{18}$ G. H. Armstrong, Origin and Meaning of Place Names in Canada, Toronto, Mac-

Millan Company of Canada, 1930, p. 298.

${ }^{19}$ Severance, op. cit., p. 4 .

${ }^{20}$ Ibid., p. 19.

"I Ibid., p. 20.

${ }^{22}$ W. F. Moore, Indian Place Names in the Province of Ontario, Toronto, Mac-

Millan Company of Canada, 1930, p. 35 .

${ }^{23}$ Severance, op. cit., p. 18, passim.

${ }^{24}$ Arthur Pound, Lake Ontario, New York, Bobbs-Merrill Co., 1945, p. 25. 